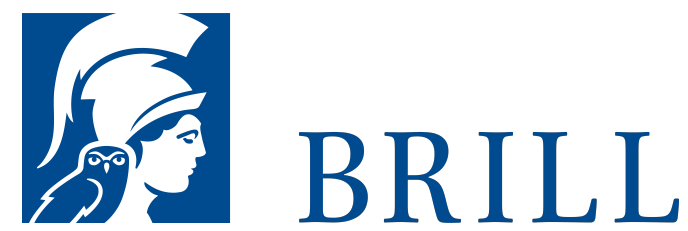

\title{
'Giftige' Gaben
}

Über Tauschprozesse in der Literatur

Author: Gisela Ecker

Theorien der Gabe beschäftigen sich häufig mit der Frage, ob es eine ,reine', uneigennützige Gabe überhaupt geben kann, und gehen meist von einem kategorialen Gegensatz zwischen Gabentausch und anderen Tauschformen aus. Literarische Texte bekümmert diese Fragen weniger. Sie erzählen Geschichten von unvollständigen, listigen, tückischen Gaben, von

Zurückweisungen, Undankbarkeiten und Verausgabungen. Gute Gaben können schnell in schlechte umkippen oder sind von vorneherein durch Euphemisierung verklärte Akte (Bourdieu). Solche Störfaktoren verstehen sich als ,Gift' der Gabe, sie halten die Narrationen am Laufen, sie kommentieren Charaktertypen und Gesellschaften. Der Band geht Geschichten vom Geben von Jane Austen bis Ilse Aichinger, von Balzac bis Böll, von Henry James bis George Tabori nach, beschäftigt sich mit dem Brot als exemplarischem Stoff der Gabe, dem Souvenir als Gattung und fragt, welche theoretischen Modelle, Gift' zulassen.

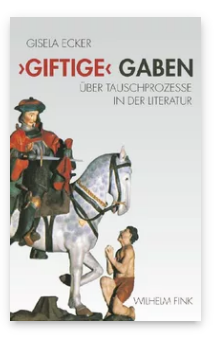

Pages: 227

Seiten

Language:

German

Subjects:

General,

Literature and

Cultural Studies

Publisher: Brill |

Fink

E-Book (PDF)

Released online:

3 o Dec 2019

ISBN: $978-3^{-}$

8467-4566-3

List price

USD $\$ 28.00$

Paperback

Publication date:

19 Mar 2008

ISBN: $978-3^{-}$

7705-4566-7

List price

USD $\$ 28.00$ 
For more information see brill.com

Order information: Order online at brill.com +44330 333 0049 | customerservices@brill.com Submission information: brill.com/authors

Titles published by Brill | Fink, Brill | mentis or Brill | Schöningh: +49(o)715413279216| brill@brocom.de 